\section{Oil in the Middle East}

Its Discovery and Development. By Stephen Hemsley Longrigg. Pp. xiii +305 . (London : Oxford University Press, 1954. Issued under the auspices of the Royal Institute of International Affairs.) 25s. net.

Tr HIS is essentially not a technical but a historical survey of Middle East oil. Scarcely anything like it has previously been published, at least for this region of oil-producing territories. The author, executive of one of the chief operating companies, has been connected with the Middle East professionally for nearly forty years (twenty-five as resident); he writes with authority and inside knowledge of men and organizations responsible for developing vast petroleum resources of Persia, Iraq, Levant and Arabia, from small beginnings to their present magnitude.

The background to these chronicles is essentially political and economic : sometimes there is peaceful co-existence between them; occasionally decidedly the opposite is portrayed, for example, in his lucid chapter "The Tragedy of Persia", one of the best objectively written accounts of what nationalization of that country's oil really meant to Britain, and still implies. The whole story of fortunes and misfortunes of Middle East oil is vividly unfolded, from early days in the nineteenth century; before, during and after the First World War ; between the Wars; and the Second World War and since. The parts played by all-American and international companies (1946-53) are not the least enlightening and valuable sections of the book.

While it deserves a conspicuous position in all libraries of the oil industry, this book will especially appeal to executives and others who have devoted their lives (and to those who still do) to founding, expanding and administering huge international petroleum undertakings, not only in the Middle East but also in other parts of the world where oilfield developments are on a comparable scale. H. B. MILNER

\section{Birds as Animals}

1: A History of Birds. By James Fisher. (Biological Sciences.) Pp. 208. (London: Hutchinson's University Library, 1954.) 8s. 6 d. net.

7 HIS work is based on the author's "Birds as

Animals", rewritten and enlarged, and is intended as a general introduction to ornithology for university students. Owing to the small size of the book, it has only been able to give a brief survey of the various aspects of the subject; but nevertheless it is a useful summary of what is known. For those who wish to pursue the subject further, there is a voluminous bibliography at the end of the book.

The first three chapters are devoted to an account of the early bird historians and more important writers, based on Newton's "Dictionary" and Cassey Wood's two volumes, which last mention several authors not available to Newton. Systematics and bird specification are dealt with in separate chapters and might well have been combined, and the same may be said of that devoted to bird history, by which the author means the geological history of birds. It is difficult to treat these subjects separately without a good deal of overlapping. In the chapter on geographical distribution we have interesting accounts of some of the birds met with by early visitors to the Americas ; but there is rather a dearth of information in regard to the East Indies and Australia. The long account of Audubon and his works might well have been replaced by more information on the birds discovered by Cook. The number of birds is a subject to which the author has paid much attention, and accordingly he devotes a chapter to tell us what he knows. Finally, there are chapters dealing with cycles, changes in numbers and the effect of man on bird populations.

N. B. KINNEAR

\section{An Introduction to Plant Physiology}

By Dr. W. O. James. Fifth edition. Pp. viii +303. (Oxford : Clarendon Press; London: Oxford Univorsity Press, 1955.) 17s. 6d. net.

7 HIS well-known and highly esteemed little book is now brought up to date by the incorporation of new material on respiration, photosynthesis, mineral nutrition, hormones, and other aspects. The insertions have mostly been woven skilfully into the older text, though a contrary instance is the inclusion of two rather different accounts of axillary bud dormancy. The mechanism of nitrogen fixation is not now so unelucidated as the author suggests.

A fow minor weaknesses persist from earlier editions; thus two different formulæ are still given for preparing molar sucrose, without explanation (and it is now implied, erroneously, that the osmotic pressure of a weight-molar sucrose solution is 34.5 atmospheres). The unqualified statements that wheat grains have never been found to survive for more than sixteen'years and that the Calluna mycorrbiza fixes nitrogen could be questioned.

For much the greater part, however, the text has the stamp of authority, and where finances permit the elementary student of botany to acquire text. books limited in scope to a single branch of the subject, this one can be strongly recommended. A first reading yielded four misprints only. G. BOND

Elementary Qualitative Analysis on the Small Scale By Dr. Peter Woodward. Pp. viii +92. (London: Oxford University Press, 1955.) 12s. 6d. net.

7 HIS essentially practical manual for sixth-form pupils and university freshmen deals with the analysis of simple mixtures of salts soluble in acids. The first of the text's five parts contains an advocacy of small-scale methods; the second describes the apparatus required and techniques recommended; the fourth deals with the chemistry of the separations and the fifth with the analysis of more difficult mixtures of anions. Although in general the schemes of analysis (Part 3) are on familiar lines, the book is unusual in its content.

Thus the author has omitted the customary long lists of reactions of the ions concerned; his outstanding contribution is the introduction into school practice of some of the new methods and principles which are revolutionizing qualitative analysis. One example must suffice-the passage of hydrogen sulphide under pressure. Dr. Woodward uses, not the elaborate apparatus described in most books but a small flask attached to an ordinary Kipp's apparatus. The reviewer can testify to the efficacy of this procedure and to the pleasure with which pupils adopt it.

With a touch of genius the author has added appendixes describing : the separation of cobalt and nickel by paper chromatography and the removal of phosphate by exchange adsorption, thus affording exercises for the abler pupils and indicating the way analysis is developing. The methods herein described should come as a boon to teachers and should help to promote a happier presentation of analysis.

G. FowLes 